\title{
Indigenous Ecological Knowledge and the Environment: The Akan Perspective
}

\begin{abstract}
There are a number of academic studies that suggest that conservational values embedded in religio-cultural thoughts could be used in collaboration with science in finding lasting solutions to the environmental problems. However, despite these abundant studies and advocacy, environmentalists have ignored these in environmental management strategies. It is against this background that this paper examines the relevance of Akan indigenous ecological knowledge to environmental management strategies in Ghana. Three qualitative techniques were employed in this study: key-informant personal interviews, participant observation and focus-group discussion. The paper argues that there are a number of resources and concepts in Akan indigenous knowledge systems that help to conserve the natural environment. It is believed that the sacredness of these conservational resources can contribute to the pursuit for effective ways of curbing the crisis, which is the ultimate objective of policy-makers. In the process, the paper engages through critical analysis the argument for and against integrating Indigenous Ecological Knowledge (IEK), in the quest for finding a lasting solution to the environmental crisis in Ghana. The paper argues that IEK contains vast knowledge and moral values that can inform contemporary conservational strategies. The paper notes that IEK ensures the survival of not only the natural environment but the people as well. The paper therefore challenges Ghanaian environmentalists, ethicists, researchers and policy-makers on the need for a critical engagement with IEK.
\end{abstract}

Keywords: Akan, Atiwa, Indigenous Ecological Knowledge, Religio-Culture Thought, Environmental Degradation, Conservation.

\section{JOSEPH KOFI ANTWI ${ }^{1}$}

${ }^{1}$ JOSEPH KOFI ANTWI, Ph.D. (Religious Studies, KNUST). His research interests are Indigenous Knowledge in African, Eco-theology African Traditional Religion. Currently, he serves on the Noguchi Memorial Institute for Medical Research Institutional Review Board (NMIMR-IRB) and a member of the African Association for Pastoral Studies and Counselling (AAPSC). He is an Ordained Minister of the Gospel in the Presbyterian Church of Ghana and currently serves as the District Minister of the North Kaneshie District.Email: kofiantwi69@gmail.com

\section{Manuscript}

Received 24th April 2020,

Accepted 15th May 2020,

Published online 18th May 2020.

\section{INTRODUCTION}

In contemporary times, issues on environmental degradation have become a foremost international worry, to the extent that "it has created an emotional crisis of despair over the planet's future." In recent times, studies and debates on the environment depicts that degradation is on the increase. The issue has become one of the major fears confronting humanity. The United Nations International Strategy for Disaster Reduction (UNISDR) describes environmental degradation as the dwindling of the limit of the earth to meet social and environmental destinations, and needs. ${ }^{3}$ Similarly, Anup Shah also insists that "if not immediately tackled, the impacts of environmental degradation can annihilate the entire environment." "It is in view of this that search for effective sustainable environmental conservation strategies become relevant.

Roger S. Gottlieb (ed.), This Sacred Earth: Religion, Nature, Environment (New York: Routledge, 2004), 8.

"Environmental Degradation" cited by Paras Shah, "Causes and Effects of Environmental Degradation.” accessed June 19, 2016.

http://www.conserve-energy-future.com/causes-and-effects-of-environmental-degradation.php.

4 Anup Shah, 'Poverty and the environment', Global Issues. 2005, accessed on August 10, 2018.

http://www.globalissues.org/article/425/poverty-and-the-environment 
In Ghana, successive governments or policy-makers have tried to put in place a number of modern measures in salvaging the numerous environmental challenges. Felix Addo-Kyere, the Eastern Regional Director of Environmental Protection Agency (EPA), for example, reveals that "many environmental management models from: science, engineering, law enforcement and policy have all been implemented to conserve, preserve, manage and sustain the natural environment, but, the results so far have been a mirage and ineffective." ${ }^{5} \mathrm{He}$ identifies the passage of environmental laws and policies, enactment of Acts, law enforcement, the creation of Fire belts around Forest Reserves, and the registration of Forest Reserves, as some of the modern techniques of environmental conservation and preservation. Ironically, all these measures can be categorised as Western models of conserving and managing the environment. This confirms Deborah McGregor's assertion that these conservational strategies have been "framed within the dominant Western Agenda... [which] does not empower indigenous nations [communities]." Moreover, it must be emphasized that these scientific strategies are also expensive in terms of finance and the personnel who will ensure their successful implementation and enforcement. ${ }^{7}$

Several Ghanaian scholars ${ }^{8}$ have all acknowledged that indigenous societies possess conservation centric values that help them to respond to environmental challenges. In their opinion these indigenous conservational values, underpinned by their religio-cultural thoughts, can contribute greatly to the search for effective environmental strategies in local communities. These scholars have maintained strongly that a return to Indigenous Knowledge (IK) could help provide sustainable insights and practical approaches to the conservation of our current ecological crises. ${ }^{9}$ This assertion is based on the fact that long before their encounter with Westernisation, indigenous Akans observe religio-cultural conservational values that helped in their relationship with the environment.

Despite the growing academic interest, as well as, their inherent environmental conservational potentials, Akan religio-cultural conservational thoughts have not received much recognition from policy-makers. The continued degradation of the environment in general and some Akan communities in Ghana in particular, for example, gives credence to the fact that Akan religio-cultural thoughts have been ignored and overlooked by policy-makers (governments of Ghana) over the years. Even though some of these communities have received a number of environmental interventions from both governmental, non-governmental organisations and other civil societies, such as A Rocha Ghana, ${ }^{10}$ the environmental problems have not been solved. It is against this background that this paper examines the relevance of Akan religio-cultural thought to environmental management strategies in Ghana. It specifically discusses the nature of these religio-cultural conservational thought, as expounded by some indigenous environmental gatekeepers. In the process the paper engages through critical analysis the assertion through the lens of Indigenous Ecological Knowledge (IEK), as the underpinning philosophical framework. The paper challenges environmentalists, theologians, ethicists and other environmental stakeholders, on the need for a critical engagement with and the usage of indigenous conservational thoughts in any contemporary conservational strategy.

\section{METHODOLOGY}

Considering the nature of the research, the 'triangulation' methodological approach was adopted. This methodological approach is the reliance on primary sources, secondary sources and personal observation strategies for the researcher's

Felix Addo Okyere, the Regional Director of the Environmental Protection Agency, in a personal interview on November 17, 2016 at his office in Koforidua, Eastern Region.

6 Deborah McGregor, “Traditional Ecological Knowledge and Sustainable Development: Toward Coexistence," in the Way of Development: Indigenous Peoples, Life Projects and Globalisation. 72 - 91. Edited by Mario Blaser et al.London: Zed Books, (2004):74.

7 Victor S. Gedzi, et al., "Environmental Reviews and Case Studies: Religious Resources and Environmental Management in Ghana." In Environmental Practice 18 no.3,(2016): 145.

8 Barfuo Akwasi Abayie-Boaten I. "Asante: The Perception and the Utilization of the Environment before the Twentieth Century." In Research Review Ns Vol.6 No.2.(1990); Y. Ntiamoa-Baidu, "Conservation of coastal lagoons in Ghana: the traditional approach." Landscape and Urban Planning, Vol. 20, Amsterdam: Elsevier Science Publishers B.V (1991):41-46; M. Entsuah-Mensah, et al., "Ghana's coastal lagoon fisheries: Is traditional management sufficient?" Unpublished Manuscript submitted to Coastal Management Journal. Washington DC, USA.(1998); Daniel K. Attuquayefio and Julius N. Fobil, "An overview of wildlife conservation in Ghana: challenges and prospects." West Afr. J. appl. Ecol. 7 (2005):1-18; Seth Appiah-Opoku, "Indigenous Beliefs and Environmental Stewardship: A Rural Ghana Experience.” Journal of Cultural Geography, 24:2, (2007): 79-98 DOI: 10.1080/08873630709478212; Paul Sarfo-Mensah, et al., "Environmental Conservation and Preservation of Cultural Heritage: Assets for Tourism Development in the Akyem Abuakwa Traditional Area of Ghana" Worldviews (2012): 4 DOI 10.1163/15685357-01700004; Samuel Awuah-Nyamekye, Managing the Environmental Crisis in Ghana: The Role of African Traditional Religion and Culture with special reference to the Berekum Traditional Area. (Cambridge: Cambridge Scholars Publishing, 2014); Beatrice Okyere-Manu, "Integrating African Indigenous Knowledge Systems into Current Ecological Conservation Strategies: Ethical Implications for Policy Makers." Intersecting African Indigenous Knowledge Systems and Western Knowledge Systems: Moral Convergence and Divergence. Edited by Beatrice OkyereManu and Herbert Moyo. Pietermaritzburg: Cluster Publications (2018):15 -29.

9 Okyere-Manu, "Integrating African Indigenous Knowledge Systems into Current Ecological Conservation Strategies: Ethical Implications for Policy Makers." 16.

10 "Protecting Atiwa Forest," accessed on August 10, 2018. https://ghana.arocha.org/projects/protecting-atiwa-forest/ 
data collection. This methodological approach assumes that "the multiple and independent methods should, if reaching the same conclusions, have greater reliability than a single methodological approach to a problem." ${ }^{11}$ According to a school of thought, since "qualitative research and analytical strategies are not associated with high-tech societies," 12 but, rather in the social and cultural milieu, it is apt to adopt it in indigenous research of this nature. In essence, it provides "meanings, concepts, definitions, characteristics, metaphors, symbols and descriptions" 13 to issues concerning the nature of things.

According to a school of thought, the culture of a society is better understood through ethnographic research. ${ }^{14}$ This was the specific research approach employed for this research. John A Saliba sees ethnography as "the process of collecting data by direct inquiry and observation and to the task of describing a particular culture or society." ${ }^{15}$ From the above, it could be deduced that the task of the ethnographic research is to give acceptable accounts of people and their social life. It is to record as accurately as possible the modes of life of other people. An anthropologist using ethnographic research methods would typically live among the people he/she intends to study and participating in some of their activities. This would involve a variety of data gathering techniques, which would eventually help the ethnographer to ask for explanations to ideals and values of community members.

As ethnographers also believe in observing people in their natural setting, so did the researcher. In order to effectively interpret, or understand, for example, the beliefs and practices of respondents within the communities, this researcher and his research assistants observed the people in their natural setting and participated in some communal events including, attending Church services, funerals, festivals and other social events. This allowed the various community members to be conversant with the research team. It also assisted the research team to gain deeper insight into the community life and culture. As an Akan, this researcher speaks the local language (Twi) and also understands the culture of the study area which helped in interpreting the realities of the communities in question.

Based on a familiarisation visit to some of the communities in identifying the target group for this research, the study identified eighteen (18) categories of interviewees, of both sexes, who were considered to be expects in issues concerning the environment within the study area. They include Atiwa environmental gatekeepers such as: chiefs, queenmothers, family heads, traditional priests and priestess, and religio-cultural (ethnomedical) healing practitioners. Others were farmers, hunters, small-scale miners, charcoal producers, chain-saw-operators, carpenters, environmentalists, teachers and officials of the district health directorate. These informants were selected because their activities and operations directly affect the natural environment. Others were considered by the townsfolk as religiocultural sages, who are repositories of environmental conservational wisdom. The study also interviewed officials of the Environmental Protection Agency in the Region, the Atiwa District Co-ordinating Directorate, and the Member of Parliament for Atiwa West.

The various categories, so identified, provided different perspectives on the issues under discussions. A total of fifty (50) participants took part in the study. Out of this number, thirty (30) were personal interviews and twenty (20) were in a focus group discussion. It must be noted that the twenty (20) participants who took part in the focus group discussions were not part of the thirty (30) people who were interviewed. The reason for this was to guarantee that key discussants were people with diverse views. It was also to enable the study to appreciate the essential issues from different perspectives. Transcripts of the field interviews, field notes, pictures, and any other related literature were coded on the bases of common themes, connections, and patterns of inter-relationships, among the various responses.

\footnotetext{
11 Muhammad Faisol Chowdhury, "Interpretivism in Aiding Our Understanding of the Contemporary Social World." In Open Journal of Philosophy, 4, (2014), 432-438, accessed January 26, 2018. http://dx.doi.org/10.4236/ojpp.2014.43047

12 Bruce L Berg, Qualitative Research Methods for the Social Science. $5^{\text {th }}$ ed. (Boston: Pearson, 2004), 2.

13 Berg, Qualitative Research Methods for the Social Science. 3.

14 "When and How to Use Ethnographic Research", accessed August 10, 2018. https://www.spotless.co.uk/insights/ethnography-when-andhow/

15 John A. Saliba, “The New Ethnography and the Study of Religion.” In Journal for the Scientific Study of Religion, Vol. 13, No. 2, (1974), 146. http://www.jstor.org/stable/1384376
} 


\section{RESULTS AND DISCUSSIONS \\ A Brief Description of the Current Environmental Situation in Atiwa, Ghana}

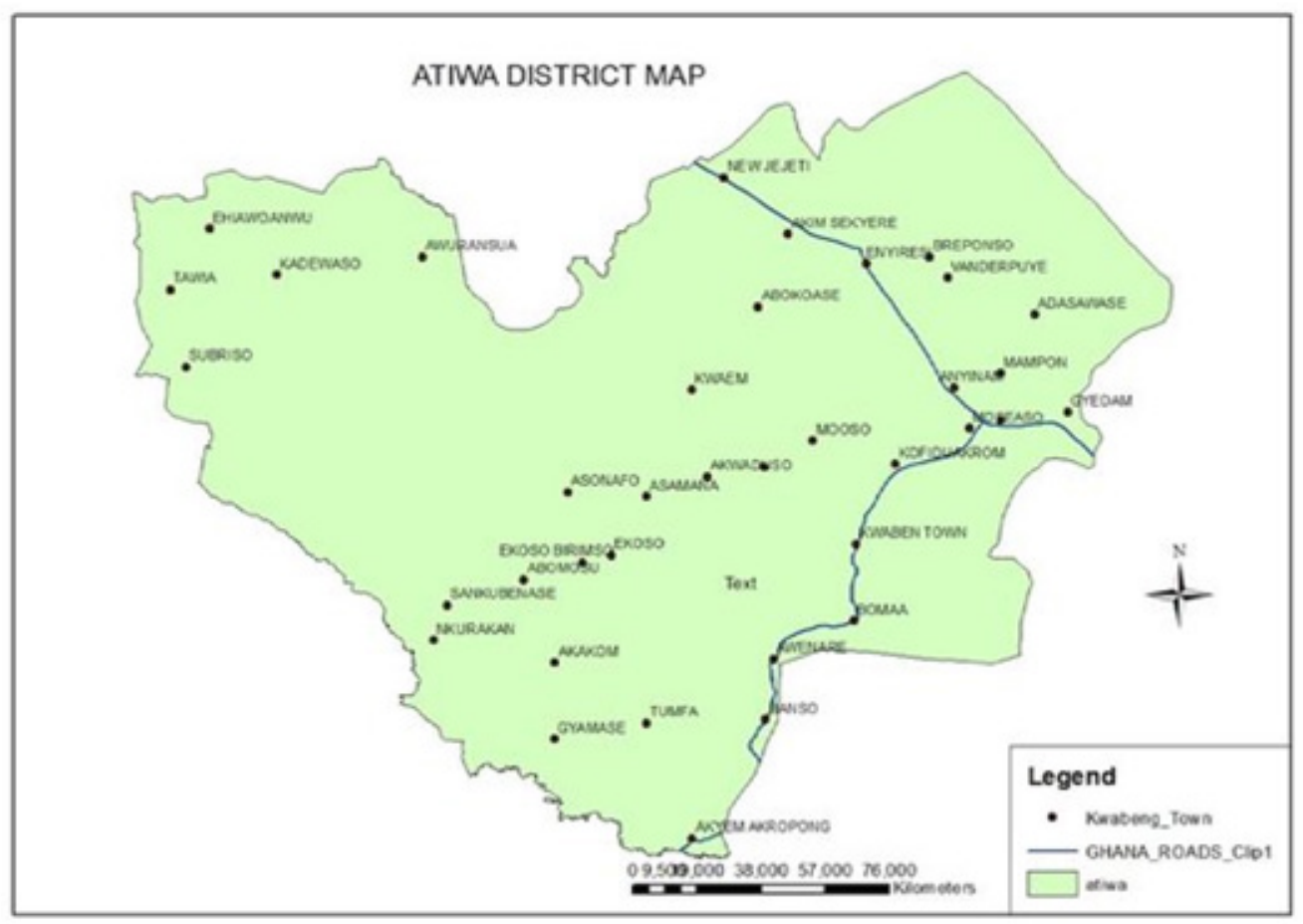

Fig.1 Map Showing Atiwa District ${ }^{16}$

One specific endemic area, where contemporary environmental interventions and conventions have not worked and the natural environment continues to be degraded, is in the Atiwa district (the study area) in the Eastern region of Ghana. Even though the district is gifted with rich natural resources, which have been very significant in the agricultural, industrial, economic and social development efforts of the district and the country at large, on the contrary, this situation has changed in recent times. According to an Environmental Protection Agency of Ghana (EPA), the environmental threats related with the extraction of the natural resources, particularly the illegal mining activities (locally known as galamsey) in the area, are wreaking havoc to both human and non-human life. ${ }^{17}$

There is a relentless degradation of the natural environment and its wealth to meet socio-economic ambitions of some people leading to depletion, exploitation, deforestation, land degradation, water pollution, health challenges, and devastation of bio-diversity among others. All these have contributed to environmental degradation in the area.

\section{Geographical and Historical Background of Atiwa}

As part of the larger Akan ethnic group, the religious thinking of the people of the Atiwa district is not different from other Akan states. This paper has therefore chosen the religio-cultural thought of the people of Atiwa as a model of the entire Akan ethnic group, of which may be made a basis for understanding the general Akan religio-cultural thought. The people of the Atiwa District belong to the Akyem (Akim) Abuakwa Traditional State. Edwin Kwame Eshun states that individuals who profess to have lineage with the Akyem heritage are called Akyemfo. ${ }^{18}$

Larger proportion of the District is very green as semi-deciduous forest. This ecological zone also promotes the cultivation and growth of certain medicinal plant, herbs and root species such as: Wawa (Tripochitonscleroxylon), Odum (miliciaexelcsa), Sapele (Guthaphragong) and Mahogany (Kaya ivoreensis). ${ }^{19}$ The climatic condition enhances agricultural production: plantain, yam, maize and cassava and other cash crops like cocoa and tobacco. The District has rich and diverse natural resources such as: gold, diamond, bauxite and kaolin, which are embedded in the Birim River

\footnotetext{
16 "Map of Ghana showing Atiwa," accessed from: https://www.researchgate.net/figure/A-Map-of-the-Atiwa-District-90.

17 “Atiwa District Assembly, Actions to Address Major Environmental Issues in the EPA Report." Ministry of Local Government \& Rural Development, (January, 2016).

18 Edwin Kwame Eshun, "Religion And Nature in Akan Culture: A Case Study of Okyeman Environment Foundation" An unpublished Masters Thesis. Queen's University Kingston, Ontario, Canada (2011):28.

19 Abusuapanyin Kwaku Danso, the Aduana Abusuapanyin of Kwabeng. In a personal interview on 12th March, 2016 in his house at Kwabeng, in the Eastern Region of Ghana
} 
around communities such as Abomosu, Anyinam, and Kwabeng. Manganese and bauxite are also deposited at Asamama and adjacent communities, whilst kaolin can be found at the Atiwa Ranges. ${ }^{20}$ The existence of these "resources have led to the emergence of illegal mining activities which has implications for water pollution, land degradation, flood and land litigation and conflict." 21

\section{Environmental Interventions in Atiwa: The Activities of A Rocha Ghana}

The environmental challenges in Atiwa have become so endemic to the extent that it has attracted a number of researches and concentrations by Governmental, Non-Governmental Organisations such as, "A Rocha Ghana." 22 It is "a conservational NGO that works in the area of biodiversity conservation. As part of its work, A Rocha Ghana collects various biodiversity data which it uses in decision making processes such as: land use planning, development of species conservation action plans, as well as advocacy." ${ }^{23}$ A Rocha aims to protect the environment through local, community-based conservation, scientific research, and environmental education. ${ }^{24}$ In Ghana, the organisation has carried out a number of research activities that aims at enlarging and campaigning for the safeguarding of existing natural and protected areas in the Atiwa Forest. ${ }^{25}$ Key among these activities is the A Rocha Ghana's Atewa [Atiwa] Critical Conservation Action Project (ACCAP 1). ${ }^{26}$

The overall goal of the project is to achieve long term protection and sustainable management of Atiwa Forest as a public good for securing livelihoods and water management, mitigating climate change impacts and conserving global biodiversity. Specifically, the project is to:

1. Improve the knowledge base, i.e. through economic valuation of ecosystem services, for informed decision making on the protection and management of the Atiwa Forest and the watersheds it feeds;

2. Address the immediate threats to the integrity of the Atiwa Forest Reserve particularly by mining activities and illegal logging and its consequences on the water basins it feeds;

3. Strengthen the position and role of local communities in the decision making processes and management of Atiwa Forest and its environs, and support direct livelihood improvement for communities;

4. Contribute to a supporting, enabling policy environment and institutional capacity for transforming Atiwa

Forest Reserve into a National Park and propose sustainable finance mechanisms for the Park and its environs. ${ }^{27}$ Notwithstanding all these conservational interventions, the degradation of the environment continues to worsen. A reason could be that the indigenous conservational values of the local people have not been engaged with yet. The lack of engagement or recognition of indigenous ecological knowledge (IEK) is making all the environmental management interventions in Atiwa unproductive.

\section{The Argument for Integrating IEK for Effective Environmental Conservation}

Indigenous Ecological Knowledge (IEK) is described as an ecological knowledge that has been invented over a long period of time, passed on by generations and has existed in indigenous communities prior to the advent of Colonialism. These scholars (Appiah-Opoku ${ }^{28}$; $\mathrm{Maweu}^{29}$; Antwi and Okyere-Manu ${ }^{30}$ ) have claimed persuasively that these IEK, which is underpinned by religious beliefs and practices, can contribute immensely to the search for effective environmental strategies in local communities "outside of Western science." 31

The embedded conservational values in IEK have been identified by other scholars. For instance, Kwadwo Konadu-Agyemang and Martin Kwamina Panford, have forcefully argued that the environmental-related behaviours by indigenous traditions are not purely the results of accrued perceptions in recent times, but, they "include years of

\footnotetext{
20 "Natural Resources", accessed September 20,2014. http://easternregion.gov.gh/index.php/atiwa/

21 Okyenhene Osagyefuo Amoatia Ofori Panin, "Galamsey in Ghana and its Health Implications." Key Note Address, at the 15th Annual Public Lecture of the Ghana Medical Association (Koforidua: Capital View Hotel, 2015),n.p.

22 http://ghana.arocha.org/

23 "Description of A Rocha Ghana," accessed on August 14, 2018. https://www.gbif.org/publisher/83cc80f4-f95f-4404-a10a-fc02aa9fee4d.

24 Johnson, Marina, "A Rocha: Spearheading the Green revolution in the church." In The Church of England Newspaper, (2008).

5 "Save Atiwa Forest," accessed August 14, 2018. http://www.saveatiwa.com.gh/

A Rocha Ghana's Atiwa Critical Conservation Action Project (ACCAP Phase I). http://www.saveatiwa.com.gh/project.php

7 “A Rocha Ghana's Atiwa Critical Conservation Action Project (ACCAP Phase I)." http://www.saveatiwa.com.gh/project.php

28 Seth Appiah-Opoku, “Indigenous Beliefs and Environmental Stewardship: A Rural Ghana Experience.” Journal of Cultural Geography, 24 no.2,(2007), 79-98 DOI: 10.1080/08873630709478212

29 Jacinta Mwende Maweu, Indigenous Ecological Knowledge and Modern Western Ecological Knowledge: Complementary, not Contradictory." Thoughts and Practice: A Journal of the Association of Kenya (PAK) New Series, Vol.3 No.2, (2011), 35-47

30 Joseph Kofi Antwi and Beatrice Okyere-Manu, "Bragro as an Akan African Indigenous Knowledge System pedagogical System: An ethical critique.” In Intersecting African Indigenous Knowledge Systems and Western Knowledge Systems: Moral Convergence and Divergence. (Pietermaritzburg: Cluster Publications, 2018), 73

31 Elizabeth Barrett Ristroph, "Integrating Community Knowledge into Environmental and Natural Resource Decision-Making: Notes from Alaska and Around the World." In Energy, Climate, \& Evn't 81 (2012), 85.
} 
analytical and experimental approach," ${ }^{32}$ to environmental conservational strategies. Again, Appiah-Opoku observes that "for thousands of years, indigenous people around the world have used experiential knowledge pertaining to their local environment to sustain themselves and to maintain their identity." ${ }^{33}$ This conservational stance assists them in their relationship with the natural environment. This affirms the views expressed by the United Nations that "traditional societies possess life-styles that can offer modern societies many lessons in the management of resources in complex forest, mountain, and dry land ecosystems. ${ }^{\prime 34}$ This indicates that contemporary societies can learn from these indigenous societies as far as conserving the environment is concerned.

Contributing to this claim that indigenous knowledge has conservational ethics that can contribute to current environmental efforts, Okyere-Manu, adds that "knowledge systems complement each other in their strengths and weaknesses, and their combination may achieve what neither would achieve alone so integrating IKS into current ecological strategies can work." ${ }^{35}$ This is based on the belief that IEK holds immense conservational potentials, which must be considered by policy-makers. For instance, there is a strong belief in most Akan communities, according to Obaapanyin Afua Dwamena, that "neophytes are made aware of why they should not go into rivers and streams, and why entry into certain places is restricted during their menstrual cycle." 36 The idea is to prevent the pollution of such river bodies in the communities. Deviants to this environmental ethic were punished accordingly. Such punishment may include a fine of lamb to pacify the river deity, and/or with the most severe punishment, being banishment from the community. Such education helps the neophyte to progress and mature with the awareness that they would not degrade the various water bodies in their communities. Thus, community members were trusted to exhibit responsible attitude towards nature, suggesting a mutual partnership with the natural environment. ${ }^{37}$

Another indigenous conservational resource that was identified from the study area is the belief in the protection of sacred groves. These are locally known as: "Nananom Mpow (ancestral groves), Assnoyeso/Abosompow (shrines), Mpayinpow (ancestral forests), and Nsamanpow (burial grounds). Osabarimah Agyare Tenadu II explains that "sacred groves are usually large tracts of forest patches which have been conserved for a long time, where citizens are not permitted to use for such places are regarded as revered spaces." ${ }^{38}$ Paul Sarfo-Mensah, et al., add that whoever violates this regulation may not find his way out of the forest. ${ }^{39}$ In the opinion of Barfuo Akwasi Abayie Boaten, "these groves are reputed to be the abodes of some respected traditional spirits. The groves had existed over the years because of taboos associated with them. Often people were forbidden to enter the groves; except when there was a ritual to be performed." ${ }^{40}$ This implies that it is a taboo, in Akan worldview, to enter the sacred groves outside the permitted period, because they are considered as "places of power." 41

From the foregoing, it is clear that religious constraints enforced on Africans by the ancestors and the fear of reprisal against the destruction of the environment is able to provide a good environmental ethic which when given the needed attention, can contribute immensely in the reduction of the current crisis. It is this religious restriction that has enabled the African to regard the natural environment as sacred. Thus, whoever degrades the environment or pollutes the rivers degrade the Supreme Being, the ancestral spirits and human beings. ${ }^{42}$ This is why Akan environmental thought ascribes values such as care, reverence, respect, to the environment. This is based on the assumption that whatever indigenous people consider to be sacred or spiritual is more likely to be revered, protected and conserved and not destroyed ${ }^{43}$ These values ensured the survival of not only the natural environment, but the people as well. Contemporary environmentalists must therefore consider indigenous knowledge as a major player in the search for effective environmental conservation.

\footnotetext{
32 Kwadwo Konadu-Agyemang and Kwamina Panford (Eds.) Africa's Development in the Twenty-First Century: Pertinent Socioeconomic and Development Issues. UK: Ashgate Publishing Company. 2006

33 Appiah-Opoku, "Indigenous beliefs and environmental stewardship: a rural Ghana experience," 82

34 Brundtland Report.djvu/27 - Wikisource, the free online library. https://en.wikisource.org/wiki/Page:Brundtland_Report.djvu/27

35 Okyere-Manu, "Integrating African Indigenous Knowledge Systems into Current Ecological Conservation Strategies: Ethical Implications for Policy Makers." 21

36 Obaapanyin Afua Dwamena, a 78 year old opinion leader in a personal interview on August $10^{\text {th }}, 2016$ at her residence at Akyem Abomosu.

37 Workineh Kelbessa, "Indigenous and Modern Environmental Ethics: Towards Partnership," In Thought and Practice in African Philosophy: Selected Papers of the Sixth Annual Conference of the International Society for African Philosophy and Studies. Edited by Gail Presbey et. al. 47-61. (Nairobi: Konrad Adenauer Foundation, 2002), 54

38 Osabarimah Agyare Tenadu II, the Chief of Kade, in the Akyem Abuakwa Traditional Area in the Eastern Region of Ghana, in a personal interview on June $16^{\text {th }} 2016$, at his palace.

39 Sarfo-Mensah, et al. "Environmental Conservation and Preservation of Cultural Heritage," 14

40 Barfuo Akwasi Abayie Boaten, “Traditional Conservation Practices: Ghana’s Example.” Research Review (NS) 14, No.1 (1998), 48

${ }_{41}$ Elizabeth Colson, "Places of Power and Shrines of the Land." Paideuma: Mitteilungen zur Kulturkunde Bd. 43, (1997):47.

42 Samuel Asiedu-Amoako, et al. "Environmental Degradation: A Challenge to Traditional Leadership at Akyem Abuakwa in the Eastern Region of Ghana." American Journal of Indigenous Studies, Vol. 1, No. 1, (2016),10

43 E. S. Leslie, et al. "Religion, Nature and Environmentalism." In Encyclopaedia of Earth. Edited by J.C. Cutler. (Washington, D.C. Environmental Information Coalition, National Council for Science and Environment, 2007) See: Awuah-Nyamekye, Managing the Environmental Crisis in Ghana, 12
} 


\section{Critique against the Integration of IEK}

Despite its acclaimed embedded indigenous values and contributions to societal development agenda, a number of criticisms have also been levelled against IEK. One of the key criticisms, against the use of indigenous knowledge is in its methodological and epistemological approach. It is argued that indigenous people who are holders of the local knowledge are not ready to explain such tacit knowledge to outsiders. ${ }^{44}$ This corroborates the views of earlier studies. For example, Arun Agrawal argues that indigenous knowledge "is closed, non-systematic, holistic rather than analytical, without an overall conceptual framework, and advances on the basis of new experiences, not on the basis of a deductive logic. ${ }^{~} 45$ This closed nature makes it difficult for the outsiders to understand their embedded values for investigation.

Another criticism is in the area of Context. Critiques of indigenous knowledge argue that "indigenous knowledge is often seen to exist in a local context, anchored to a particular social group in a particular setting at a particular time, as such it is difficult to divorce from an epistemic framework into a universal validity." 46 This posits that unless the investigator or researcher (outsiders) lives within that context or interpreting the values within such indigenous knowledge could be carried only by those from that particular context. This makes it difficult for 'university validity' of such indigenous knowledge. This situation poses socio-political, ethical and cultural challenges to outside researchers.

There is also the issue of the mode of transmission of the local knowledge. Indigenous ecological knowledge is orally transmitted, but not documented. This poses a hindrance to any contemporary inquiry of such ecological knowledge. The cost involved in documenting such oral traditions serves as disincentive for policy makers and other researchers to rely upon.

From the above insights three important views can be deduced. The first is that indigenous knowledge is associated with a particular people's tradition and cultural settings. This implies that the knowledge is initially restricted to those who created it to deal with their immediate needs. It means that it can only be shared by those with similar needs of life.

The second point is that indigenous knowledge is specific in both time and space. This means that IEK has a point at which it began to be used within a specific spatial location or context. To be able to discover such knowledge, there is the need for present researchers to go back in time and uncover such location where the knowledge was first used.

The third point in relation to the above is that IEK is more often related with the original inhabitants of a particular geographical location who have a distinct religio-cultural thought. This is to say, indigenous knowledge is cultural-specific and its relevance is limited to how such knowledge is applied by that specific people. Thus, IK is employed as a way of life for everyday existence within specific cultural milieu, including their relationship with the environment. This affirms the views expressed by the United Nations that "traditional societies possess life-styles that can offer modern societies many lessons in the management of resources in complex forest, mountain, and dry land ecosystems." 47

A school of thought argues that indigenous traditions know better than the world's expansionist, agricultural civilizations, on how to live harmoniously in their environment ${ }^{48}$ and "they have high sustainability potential." ${ }^{49}$ Thus, they are the first to detect when the forests are being threatened, and to feel the pollution of their waters. However, they are the last to be consulted about environmental sustainability ${ }^{50}$ IEK, thus, provides lessons that can inform and transform the contemporary environmental strategies. ${ }^{51}$

The above assertion also supports the argument that solving the environmental crisis at the local level cannot be an isolated effort. For instance, Attuquayefio and Fobil were right when they aptly observed that "many of the environmental conservation initiatives in the developing countries (particularly in Africa) have not been effective

44 Elina Helander Renwall and Inkeri Markkula, "On Transfer of Sami Traditional Knowledge: Scientification, Traditionalization, Secrecy and Equality," in Indigenous Peoples' Cultural Heritage: Rights, Debates, Challenges. Edited by Alexandra Xanthaki, (ed.) et al., (Brill Nijhoff: Leiden, 2017), 117

45 Arun Agrawal, "Indigenous and scientific knowledge: some critical comments." IK Monitor 3(3) (1995), 3. (Accessed on March 20"th 2016) http://www.nuffic.ni/ciran.ikdm/3-3/article/agrawal.html.

46 T. Banuri and F. Apffel-Marglin. (eds). Who will save the forests? Knowledge, power and environmental destruction. (London, Zed Books, 1993), 11-13.

47 Brundtland Report.djvu/27, Wikisource, the free online library. https://en.wikisource.org/wiki/Page:Brundtland_Report.djvu/27

48 Bron Taylor, "Foreword" in Managing the Environmental Crisis in Ghana: The Role of African Traditional Religion and Culture with special reference to the Berekum Traditional Area. (Cambridge: Cambridge Scholars Publishing, 2014), xii.

49 Charles Takoyoh Eyong, "Indigenous Knowledge and Sustainable Development in Africa: Case Study on Central Africa," Center for Development Research, University of Bonn,accessed on September 15, 2015. http://www.zef.de/module/register/media/deed_Chapter12 Eyong-C-Takoyoh.pdf.

50 President, Native Council of Canada: WCED Public Hearing Ottawa, In the Brundtland Report: Our Common Future. New York, Oxford University Press (1987), 68.

51 Okyere-Manu, "Integrating African Indigenous Knowledge Systems into Current Ecological Conservation Strategies: Ethical Implications for Policy Makers," 21. 
because of the tendency to overlook the essential link between traditional and scientific ways of conserving the environment." ${ }_{52}$ It is the position of this paper that for environmental conservational initiatives to be effective it requires a deeper reflection, by policy-makers and a collaborative effort with the local knowledge. Thus, contemporary Ghanaian policy-makers, including environmental managers, must acknowledge, respect and factor the embedded religio-cultural ecological values of indigenous communities, in their quest to finding lasting solutions to the environmental problems in Ghana.

\section{AKAN RELIGIO-CULTURAL THOUGHT AS AN INDIGENOUS CONSERVATIONAL RESOURCE}

A key element of the encounter between the Western worldview and that of African worldview was the notion that indigenous people in general are incapable of formulating a philosophical treaty, which is "complete with an adequate vocabulary." ${ }^{53}$ In their appraisal, Akan religio-cultural thought, as a paradigm of African Traditional [Indigenous] Knowledge in general, lack philosophical inquiry. The effect of this destructive assessment of African indigenous thinking has resulted in accepting everything indigenous as of 'no-value.' In the opinion of Abusuapanyin Kwaku Danso, "Western scholars, missionaries and colonizers marred our history and concocted a false perspective on our religio-cultural beliefs and practices, which they presented as pre-logical, barbaric and as such, they considered us as being incapable of thought." ${ }^{4}$ The natural result of this Western view of Africa was a tendency, in the view of Lovemore Ndlovu, "was to treat anything pre-Christian in Africa as either harmful or at best valueless, and to consider the African once converted from paganism as a sort of tabula rasa, on which a whole new religious psychology was somehow to be imprinted." 55 This corroborates similar assertion by Uduma U. Oji that "some European scholars such as Kant, Hegel, and Levy-Bruel, considered Africans as culturally naïve, intellectually docile and rationally inept." ${ }^{56}$ This means that Africans were incapable of intellectual discourse.

The uniqueness of African religio-cultural thoughts and its institutions, or the African identity, received a bolster during the colonial era, from Edward Wilmot Blyden. In his response to the religio-cultural uniqueness of Africans, he wrote, "the African has developed and organised a system useful to him for all the needs of life, a system as his environment have suggested, to be improved not changed by larger knowledge." 57 It was in such valid system that Blyden sought to portray in his description of the religio-cultural thoughts regarding, the family, community living, care for the environment, moral values, beliefs, practices and other religio-cultural institutions. Proponents of indigenous religio-cultural philosophy argue that the lack of written literature does not imply the absence of philosophical thinking.

The above notwithstanding, the indigenous philosophical outputs of African thinkers in the traditional settings have remained part of their oral traditions. Data from the field revealed that indigenous people have been nurturing, instructing or disseminating ecological knowledge through oral traditions over the years long before their encounter with Europeans. Consequently, the undocumented nature of indigenous thoughts does not under any circumstance reduce or devalue the conservational potential of such knowledge. But the question that confronts this paper is the methodology by which such integration should take place in the current globalised world.

\section{VALUING AKAN CONSERVATIONAL THOUGHTS}

In pursuing a long-term solution to the environmental crisis, this paper reveals that even though there is an increase in conservational awareness through scholarly works, integrating such indigenous conservational thoughts or values into current conservational strategies in Ghana, by policy makers, has been the missing link. This article maintains that the implementation of environmental management strategies in Ghana has been approached from one perspective; that is, from the Western scientific approach only. Such a one-sided conservational approach has restricted and continues to inhibit an all-inclusive approach to finding a lasting solution to the numerous environmental challenges in Ghana; especially where diverse conservational potential abounds in the various local communities.

The proposal to integrate IEK into current conservational efforts is based on the following characteristics: that IEK contains vast knowledge and moral values that can inform contemporary developmental agenda. This has been

tested, tried and proven to be effective by African indigenous people. Again, IEK is inexpensive in terms of finance and human resource; it is easier and can generate rapid results. It reveres, cares, respects and protects nature and considers it as sacred, something to be conserved. These characteristics make IEK a strong pillar in environmental conservation,

\footnotetext{
${ }_{52}$ Attuquayefio and Fobil, "An overview of wildlife conservation in Ghana: challenges and prospects.” West Afr. J. appl. Ecol. 7 (2005), 1-18.

53 Placide Temples, Bantu Philosophy (Luabo-Kamina: Imprimi Potest, 1959), 17.

${ }^{4}$ Abusuapanyin Kwaku Danso, in a personal interview on 12th March, 2016 in his house at Kwabeng, Eastern Region

55 Lovemore Ndlovu, "The African Apostolic Church led by Paul Mwazha as a Response to Secularization," in Multiplying in the Spirit: African Initiated Churches in Zimbabwe. Edited by Ezra Chitando, et.al. (University of Bamberg Press: Nurnberg, 2014), 55

56 Uduma Uduma Oji, "The Question of the "African.' In African Philosophy: In Search of a Criterion for the Africanness of a Philosophy," FilosofiaTheoretica: Journal of African Philosophy, Culture and Religions. 3 no.1 (2014), 127-143

57 Edward Wilmot Blyden, African Life and Customs (Baltimore: Black Classic Press, 1994), 10.
} 
especially in indigenous communities.

In proposing the integration of IEK into current conservational strategies, this paper admits however, that there are certain aspects of the indigenous beliefs and practices that may not be convenient or ideal in the current globalised world. Certain religio-cultural practices contribute to the extinction of some plants and animal species, especially the hunting of wild animals during the observance of festivals. Such religio-cultural practices and beliefs may not be in consonance with modern conservational practices.

This notwithstanding, it is recommended that firstly, the relevant aspects of religio-cultural thoughts on conservation would experience some refining to become completely functional with science in the management of the environment in post-colonial Ghana. Such a process need not necessarily weaken the importance of either knowledge system, but rather, the integration of the two systems within the context of devolution. As Peter J. Usher notes, devolution takes two forms; first is the movement of authority and responsibility from a higher to a lower level within an established and intact framework. ${ }^{58}$

The second is the actual transfer of authority and responsibility from one system to another. ${ }^{59}$ Thus, the notion of devolution underscores the urgent need for policy makers, natural resource managers and relevant environmental stakeholders to decentralize the control and supervision of the management of the natural environment in the hands of local environmental gate-keepers. It is therefore recommended that the control and management of the Atiwa forest reserve, for example, could be decentralized with the active participation of the local people.

It is further recommended that indigenous people who are regarded as "expects," due to their far-reaching religio-cultural knowledge of the local environment, would be made to serve as partners with scientific experts on Committees and Boards that formulate, review or implement environmental policies at the Local, Regional and National levels. This will enable the indigenes to have a sense of ownership and identity of those policies and also be responsible in conserving their natural environment. Decision arrived at such collaborative efforts would be acceptable by both the indigenous and the scientific audience. The criteria for inviting indigenous experts should include such variables as gender, age, social status, occupation, and possibly linguistic abilities.

It must be noted that the inability of policy makers, or successive governments of Ghana, in incorporating religio-cultural conservational values into contemporary environmental management strategies, is to stress that there is a "religio-cultural root" to the environmental crisis in Ghana. By their actions, whether consciously or unconsciously, Ghanaian policy makers are underscoring the colonial mentality that everything religio-cultural, or pre-colonial is primitive, outmoded, out-dated or heathen and in need of scientific renewal. This has promoted a new civilization, where everything Western is preferred to indigenous systems. This misconception, however, limits the way and manner these religio-cultural conservational values are perceived within contemporary discourse. Such a situation does not encourage Ghanaian policy makers to consider the proven religio-cultural thoughts as alternative means of development.

Again, analysis of the research data disclosed that the "supposed beneficiaries" of these current conservational models; who are the local people, regard these Western conservational models as "alien." In that, they are not able to identify with, or be associated with it. The reason is that their proven religio-cultural conservational strategies are not factored into such 'foreign' conservational methods. Thus, there is the possibility of affecting their sustainability in the various communities. There is therefore the need for the local people to identify themselves with such conservational strategies and ensure their sustainability in their communities.

Stressing on the incorporation also emphasises that there is the urgent need for policy makers to re-examine themselves, to incorporate these religio-cultural values into current environmental management strategies. Such an introspective assessment would afford the policy-makers to realise that conservational policies they formulate are religio-cultural centric in nature, which are based on the worldviews of the targeted beneficiaries. It would also be a catalyst in giving the needed recognition to religio-cultural thoughts in Ghana.

\section{CONCLUSION}

This paper has made the case that there is a place for Akan religio-cultural thoughts in environmental management in Ghana. It maintained that in finding lasting solution to the numerous environmental problems in Ghana, or reversing the problem in the Atiwa district, for example, there is the urgent need for policy makers and other stakeholders, to incorporate these religio-cultural environmental conservational potentials into environmental management. It is also pertinent to note that environmental managers, policy makers and other stakeholders must view religio-cultural environmental conservational thoughts, in particular and indigenous knowledge in general, as vital to the wholistic

\footnotetext{
58 Peter J. Usher, "Sustenance or Recreation? The Future of Native Wildlife Harvesting in Northern Canada." In Proceedings: First International Symposium on Renewable Resources and the Economy of the North. Edited by M.M.R. Freeman. Association of Canadian Universities for Northern Studies, Ottawa. 56-71, (1981), 56-7 1.

59 Usher, "Sustenance or Recreation? 56
} 
development of Ghana. Such knowledge pool, it must be pointed out, involves aspect of the life and thought of an ongoing community.

\section{BIBLIOGRAPHY}

Agrawal, Arun. "Indigenous and scientific knowledge: some critical comments." IK Monitor 3 no. 3 (1995). Accessed on March 20, 2016. http://www.nuffic.ni/ciran.ikdm/3-3/article/agrawal.html.

Agyekum, Kofi “Aspects of Akan Oral Literature in the Media." Research Review New Series 16.2. (2000), 1-18 Akonor, K. Kwadwo Konadu-Agyemang and Kwamina Panford (Eds.) Africa's Development in the Twenty-First Century: Pertinent Socioeconomic and Development Issues. UK: Ashgate Publishing Company. May 2006. J Afr Am St 13, 372-373 (2009). https://doi.org/10.1007/s12111-009-9090-9

Antwi, Joseph Kofi and Beatrice Okyere-Manu. "Bragro as an Akan African Indigenous Knowledge System pedago gical System: An ethical critique." In Intersecting African Indigenous Knowledge Systems and Western Knowledge Systems: Moral Convergence and Divergence. Pietermaritzburg: Cluster Publications, (2018), 73-87

Appiah-Opoku, Seth. "Indigenous Beliefs and Environmental Stewardship: A Rural Ghana Experience." Journal of Cultural Geography, 24:2, (2007), 79-98. DOI: 10.1080/08873630709478212

Appiah-Opoku, Seth. Indigenous Institutions: A Resource For Environmental Impact Assessment And Planning In Ghana. An unpublished PhD Thesis. Waterloo, Ontario, Canada, (1997)

Asante, C. "Folktale and environmental education." In cahiers du Centre d'Etudes et de Recherche en Lettres Sciences Humaines et Sociales. Edited by A. Napon, (CERLESHS), 5e numero special. (2005), 101-112

Asante-Darko, Kwaku. "Ecocriticism and environmental knowledge of Asante oral traditional poetry." An unpublished PhD. Thesis. University of the Witwatersrand, Johannesburg, South Africa, (2006)

Asiedu-Amoako, Samuel. et al. "Environmental Degradation: A Challenge to Traditional Leadership at Akyem Abuakwa in the Eastern Region of Ghana." American Journal of Indigenous Studies, Vol. 1, No. 1, (2016), 1-13

Atiwa District Assembly, Actions to Address Major Environmental Issues in the EPA Report. Ministry of Local Government \& Rural Development, January, (2016)

Attuquayefio, Daniel K. and Julius N. Fobil, "An overview of wildlife conservation in Ghana: challenges and prospects." West Afr. J. appl. Ecol. 7 (2005), 1-18

Awuah-Nyamekye, Samuel. Managing the Environmental Crisis in Ghana: The Role of African Traditional Religion and Culture with special reference to the Berekum Traditional Area. Cambridge: Cambridge Scholars Publish ing, (2014)

Banuri, T. and F. Apffel-Marglin (eds.), Who will save the forest? Knowledge, power and environmental destruction. London: Zed Books, 1993

Bediako, Kwame. Theology and Identity: The Impact of Culture upon Christian Thoughts in the Second Century and the Modern Africa. Cumbria: Regnum Books, 1992

Berg, Bruce L. Qualitative Research Methods for the Social Science. 5th ed. Boston: Pearson, 2004

Blyden, Edward Wilmot. African Life and Customs. Baltimore: Black Classic Press, 1994

Boamah, Daniel Asante. Akan Indigenous Religio-Cultural Beliefs and Environmental Preservation: the Role of Taboos. An unpublished Masters Thesis. Queen's University. 2015

Boaten, Barfuo Akwasi Abayie "Traditional Conservation Practices: Ghana’s Example." Research Review (NS) 14, No1. (1998), 48

Boaten, Barfuo Akwasi Abayie. "Asante: The Perception and the Utilization of the Environment before the Twentieth Century." In Research Review Ns Vol.6 No.2. (1990)

Brundtland Report.djvu/27 - Wikisource, the free online library. https://en.wikisource.org/wiki/Page:Brundtland_Re port.djvu/27

Banuri, T. and F. Apffel-Marglin. (eds). Who will save the forests? Knowledge, power and environmental destruction. London, Zed Books, 1993

Chowdhury, Muhammad Faisol. "Interpretivism in Aiding Our Understanding of the Contemporary Social World." In Open Journal of Philosophy, 4, (2014), 432-438 Accessed on January 26th, 2018 http://dx.doi.org/10.4236/ojpp.2014.43047.

Colson, Elizabeth. "Places of Power and Shrines of the Land." Paideuma: Mitteilungen zur Kulturkunde Bd. 43, (1997), 47-57

Entsuah-Mensah, M. et al., “Ghana's coastal lagoon fisheries: Is traditional management sufficient?” Unpublished 
Manuscript submitted to Coastal Management Journal. Washington DC, USA.(1998), n.p.

Eshun, Edwin Kwame. "Religion And Nature in Akan Culture: A Case Study of Okyeman Environment Foundation" An unpublished Masters Thesis. Queen's University Kingston, Ontario, Canada. (2011)

Eyong, Charles Takoyoh. "Indigenous Knowledge and Sustainable Development in Africa: Case Study on Central Africa," Center for Development Research, University of Bonn. Accessed September 15th, (2015) http://www.zef.de/module/register/media/deed_Chapter12_Eyong-C-Takoyoh.pdf.

Gedzi, Victor S. et al., "Environmental Reviews and Case Studies: Religious Resources and Environmental Manage ment in Ghana." In Environmental Practice 18:3, (2016),137-147

Gottlieb, Roger S. "Religious Environmentalism in Action," in The Oxford Handbook of Religion and Ecology. Edited by Roger Gottlieb. New York: Oxford University Press, 2006.

DOI:10.1093/acprof:oso/9780195176483.003.0006

Hammersley, M. Educational Research: Current Issues. London: Sage Publications, 2003 Jouanjean, Marie Agnes et al.,"Understanding the effects of resource degradation on socio-economic outcomes in developing countries.” (2014). Accessed on September 11th, 2016 https://www.odi.org/sites/odi.org.uk/files/odi-assets/ publications-opinion-files/8830.pdf.

Kelbessa, Workineh "Indigenous and Modern Environmental Ethics: Towards Partnership," Thought and Practice in African Philosophy: Selected Papers of the Sixth Annual Conference of the International Society for African Philosophy and Studies. Edited by Gail Presbey et. al. 47-61, Nairobi: Konrad Adenauer Foundation, 2002,

Leslie, E. S. et al. "Religion, Nature and Environmentalism." In Encyclopaedia of Earth. Edited by J.C. Cutler. Wash ington, D.C. Environmental Information Coalition, National Council for Science and Environment, 2007

Marina, Johnson. "A Rocha: Spearheading the Green revolution in the church. ” In The Church of England Newspaper, (2008), n.p.

Maweu, Jacinta Mwende. "Indigenous Ecological Knowledge and Modern Western Ecological Knowledge: Complementary, not Contradictory." Thoughts and Practice: A Journal of the Association of Kenya (PAK) New Series, Vol.3 No.2, (2011), 35-47

Ndlovu, Lovemore, “The African Apostolic Church leb by Paul Mwazha as a Response to Secularization." In Multiply ing in the Spirit: African Initiated Churches in Zimbabwe. Edited by Ezra Chitando, et.al. University of Bamberg Press: Nurnberg, (2014)

Ntiamoa-Baidu, Y. "Conservation of coastal lagoons in Ghana: the traditional approach." Landscape and Urban Planning, Vol. 20, (1991), 41-46.

Oji, Uduma Uduma. "The Question of the 'African.' In African Philosophy: In Search of a Criterion for the Africanness of a Philosophy." In FilosofiaTheoretica: Journal of African Philosophy, Culture and Religions. 3 no.1, (2014), 127-143

Okyenhene Osagyefuo Amoatia Ofori Panin, "Galamsey in Ghana and its Health Implications." Key Note Address, at the 15th Annual Public Lecture of the Ghana Medical Assocation, Koforidua: Capital View Hotel, (2015), n.p.

Okyere-Manu, Beatrice and Herbert Moyo (eds.), Intersecting African Indigenous Knowledge Systems and Western Knowledge Systems: Moral Convergence and Divergence. Pietermaritzburg: Cluster Publications, 2018

Okyere-Manu, Beatrice. "Integrating African Indigenous Knowledge Systems into Current Ecological Conservation Strategies: Ethical Implications for Policy Makers.” In Intersecting African Indigenous Knowledge Systems and Western Knowledge Systems: Moral Convergence and Divergence. Pietermaritzburg: Cluster Publica tions, (2018), 15-29

Renwall, Elina Helander and Inkeri Markkula, "On Transfer of Sami Traditional Knowledge: Scientification, Tradi tionalization, Secrecy and Equality.” Edited by Alexandra Xanthaki, (ed.) et al., Indigenous Peoples'Cultural Heritage: Rights, Debates, Challenges. Brill Nijhoff: Leiden, (2017), 117

Saliba, John A. "The New Ethnography and the Study of Religion." Journal for the Scientific Study of Religion, Vol. 13, No. 2 (1974),145-159. http://www.jstor.org/stable/1384376

Sarfo-Mensah, Paul et al., "Environmental Conservation and Preservation of Cultural Heritage: Assets for Tourism Development in the Akyem Abuakwa Traditional Area of Ghana" Worldviews. (2012).

DOI 10.1163/15685357-01700004

Shah, Anup. 'Poverty and the environment', Global Issues. (2005). Accessed August 10 ${ }^{\text {th }}, 2018$ http://www.globalis sues.org/article/425/poverty-and-the-environment

Silverman, D. Qualitative Research: Theory, Method and Practice. London: Sage Publications, 2004

Temples, Placide, Bantu Philosophy. Luabo-Kamina: Imprimi Potest, 1959

Tomlinson, Dave. The Post-Evangelical: SPCK Classic - with a new Preface. London: Society for the promotion of Christian knowledge, 1995 
MOTBIT Volume 2 Issue 1 - April 2020 pp 58 - 69

Usher, Peter J. "Sustenance or Recreation? The Future of Native Wildlife Harvesting in Northern Canada." In Pro ceedings: First International Symposium on Renewable Resources and the Economy of the North. Edited by M.M.R. Freeman. Association of Canadian Universities for Northern Studies, Ottawa (1981), 56-7 1. 